\title{
Identification and Characterization of Isolates of Pythium and Phytophthora spp. from Snap Beans with Cottony Leak
}

J. D. Olson and J. P. Damicone, Department of Entomology and Plant Pathology, and B. A. Kahn, Department of Horticulture and Landscape Architecture, Oklahoma State University, Stillwater 74074

\begin{abstract}
Olson, J. D., Damicone, J. P., and Kahn, B. A. 2016. Identification and characterization of isolates of Pythium and Phytophthora spp. from snap beans with cottony leak. Plant Dis. 100:1446-1453.

Cottony leak is an important disease of snap bean in Oklahoma and nearby states. Oomycete pathogens isolated from diseased pods collected from commercial fields and research plots consisted of both Pythium spp. $(n=131)$ and Phytophthora spp. $(n=46)$. Isolates were identified to species by morphological characteristics and by sequencing a portion of the internal transcribed spacer region of representative isolates. The most common Pythium spp. were Pythium ultimum var. ultimum; Pythium 'group HS', a self-sterile form of $P$. ultimum that produces hyphal swellings in lieu of sporangia $(n=74)$; and $P$. aphanidermatum $(n=50)$. Phytophthora spp. included Phytophthora drechsleri $(n=41)$ and $P$. nicotianae $(n=5)$. Nearly all of the isolates $(95 \%)$ and all species were pathogenic on detached pods but Pythium ultimum var. ultimum and Pythium 'group HS' were most aggressive. Phytophthora drechsleri

was most aggressive on seedlings, causing preemergence damping off and seed rot. Pythium ultimum var. ultimum, Pythium 'group HS', and $P$. aphanidermatum were intermediate in virulence to seedlings, causing root rot, stunting, and limited postemergence damping off. Phytophthora nicotianae and Pythium diclinum $(n=4)$ were not pathogenic on seedlings. Most (87\%) isolates were sensitive to metalaxyl-M (concentration that caused a 50\% reduction in mycelial growth $\left[\mathrm{EC}_{50}\right]<1 \mu \mathrm{g} / \mathrm{ml}$ ) and the rest were intermediate in sensitivity $\left(\mathrm{EC}_{50}>1\right.$ to $\left.<100 \mu \mathrm{g} / \mathrm{ml}\right)$ Phytophthora drechsleri was the most sensitive species $\left(\mathrm{EC}_{50}=\right.$ $0.06 \mu \mathrm{g} / \mathrm{ml}$ ) compared with Pythium aphanidermatum, which was least sensitive $\left(\mathrm{EC}_{50}=1.3 \mu \mathrm{g} / \mathrm{ml}\right)$. Cottony leak is a disease complex caused by several oomycete species that should include Phytophthora drechsleri, a newly reported pathogen of snap bean in the United States.
\end{abstract}

The oomycetes Pythium and Phytophthora spp. are important pathogens of snap bean (Phaseolus vulgaris L.) and other Phaseolus spp. Pythium spp. cause diseases with both subterranean and aerial phases (Pfender 1991). The subterranean phases typically affect seedlings and young plants and include seed rot, pre- and postemergence damping off, root rot, and basal stem rot. Pythium ultimum Trow, $P$. myriotylum Drechsler, and $P$. aphanidermatum (Edson) Fitzp. are the most important subterranean pathogens, depending on the production region (Drechsler 1952; Lumsden et al. 1976; Pfender 1991; Pieczarka and Abawi 1978). The aerial phases of bean diseases caused by Pythium spp. affect upper stems, leaves, and pods. Pythium blight caused by Pythium debaryanum R. Hesse and P. ultimum (Adegbola and Hagedorn 1969; Hagedorn 1991) occurs where infested water and soil are splashed onto lower leaf nodes and the foliage remains wet. Pod decay caused by P. aphanidermatum is referred to as cottony or Pythium leak (Harter and Whitney 1927) and occurs on mature plants near harvest in the field and postharvest when beans are in transit to processing facilities.

Bean diseases caused by Phytophthora spp. affect primarily pods and are collectively referred to as downy mildew (Schwartz 1991). Phytophthora phaseoli Thaxt. causes downy mildew of lima bean (Phaseolus lunatus L.), a severe problem in Delaware and Maryland (Evans et al. 2007). Phytophthora nicotianae Breda de Haan is reported to cause downy mildew of bean pods in tropical climates but not in the United States (Schwartz 1991). P. capsici Leonian has been reported to cause foliar and pod blight of snap bean in Michigan (Gevens et al. 2008) and pod decay resembling downy mildew on lima bean (Evans et al. 2007).

Snap bean (Phaseolus vulgaris L.) is an important vegetable crop grown for processing in the region of eastern Oklahoma, Arkansas,

Corresponding author: J. P. Damicone; E-mail: john.damicone@okstate.edu Accepted for publication 10 February 2016.

http://dx.doi.org/10.1094/PDIS-06-15-0662-RE

(C) 2016 The American Phytopathological Society and Missouri. The crop is machine harvested in bulk with nonselective pickers prior to transport to the processing facility, where little sorting is done to remove blemished pods. Therefore, the crop is managed to be nearly free of blemishes from disease and other pests. Pod decay caused by oomycetes is a problem in the region (Damicone et al. 2012; Taylor and Rothrock 2006) and may decrease the marketability of pods for processing. Symptoms first appear on basal pods in contact with soil or plant debris as water-soaked or reddish-brown lesions. Lesions expand, become soft and watery, and develop profuse amounts of white cottony mycelium. Fields with a high incidence of diseased pods may be rejected for harvest, resulting in a total economic loss. Fields with a low incidence of disease may be harvested but the disease can increase in bulk containers used for transport and storage prior to processing (Harter and Whitney 1927).

Except for a brief report of Pythium aphanidermatum causing cottony leak of bean in Oklahoma (Preston 1945), little is known about the oomycetes that cause pod decay in Oklahoma and the surrounding production region. $P$. aphanidermatum was initially identified in a field in Missouri and used to inoculate field trials for evaluating disease management strategies (Damicone et al. 2012). Subsequent isolations made from diseased pods collected from problem fields in Oklahoma and in Arkansas and Missouri (Taylor and Rothrock 2006) indicated that additional oomycetes, including other Pythium spp. and Phytophthora spp., are involved. Identification of the oomycete species involved and knowledge of their occurrence, pathogenicity to pods, and fungicide sensitivity is critical for identifying the primary pathogens and developing effective disease management strategies. For example, the resistance of bean cultivars to Pythium blight (Adegbola and Hagedorn 1970), Pythium damping off (Lucas and Griffiths 2004), and Pythium leak (Damicone et al. 2012) may not be effective against all oomycete species that attack bean. The phenylamide fungicide metalaxyl and its isomer metalaxyl-M (Fungicide Resistance Action Committee [FRAC] group 4) are systemic fungicides used extensively to control diseases caused by oomycete pathogens. Metalaxyl and metalaxyl-M resistance has been reported for several Pythium and Phytophthora diseases (Gevens et al. 2008; Hunger et al. 1982; Matheron and 
Porchas 2000; Mazzola et al. 2002; Moorman et al. 2002; Parra and Ristaino 2001; Sanders 1984; Taylor et al. 2002; van Jaarsveld et al. 2002). Determining the metalaxyl-M sensitivity of oomycetes that cause pod decay in our region is important for making fungicide recommendations and monitoring fungicide resistance. Therefore, the objectives of this research were to identify the oomycete species that cause pod decay of snap bean in the region and to characterize their relative pathogenicity, virulence, and sensitivity to metalaxyl-M.

\section{Materials and Methods}

Isolation and morphological identification. Diseased pods were collected from commercial snap bean fields $(n=5)$ in eastern Oklahoma and southwestern Missouri and research plots $(n=5)$ at the Oklahoma Vegetable Research Station in Bixby, OK from 2002 to 2007. Disease pods were collected and either the pods were washed under running tap water for $16 \mathrm{~h}$ and sectioned, or pod sections were surface disinfested in $70 \%$ ethanol for $30 \mathrm{~s}$ and $0.6 \%$ sodium hypochlorite for $1 \mathrm{~min}$ and rinsed in sterile distilled water. Pod sections were placed onto selective media containing corn meal agar amended with pimaricin at 5 or $10 \mathrm{mg} /$ liter $\left(\mathrm{P}_{5}\right.$ or $\left.\mathrm{P}_{10}\right)$, ampicillin at $250 \mathrm{mg} /$ liter (A), rifampicin at $10 \mathrm{mg} /$ liter (R), pentachloronitrobenzene (PCNB) at $100 \mathrm{mg} / \mathrm{liter}(\mathrm{P})$, vancomycin at $200 \mathrm{mg} / \mathrm{liter}(\mathrm{V})$, and hymexazol at $50 \mathrm{mg} /$ liter as $\mathrm{P}_{5} \mathrm{ARP}, \mathrm{P}_{10} \mathrm{VP}$, and $\mathrm{P}_{10} \mathrm{VPH}$ (Jeffers and Martin 1986), or $1.5 \%$ water agar, and incubated in the dark at 22 to $25^{\circ} \mathrm{C}$ for 24 to $72 \mathrm{~h}$. Colonies characteristic of oomycetes were transferred to $1.5 \%$ water agar at 22 to $25^{\circ} \mathrm{C}$ for 24 to $48 \mathrm{~h}$. Isolates were then transferred to clarified V8 juice agar (CV8; $1 \mathrm{~g}$ of $\mathrm{CaCO}_{3}$ per $100 \mathrm{ml}$ of $\mathrm{V} 8$ juice, clarified by centrifugation at 7,000 rpm for $10 \mathrm{~min}$, the supernatant decanted and kept; $200 \mathrm{ml}$ of clarified V8 juice $+15 \mathrm{~g}$ of agar per liter) or potato carrot agar (broth from boiling $20 \mathrm{~g}$ of carrot and $20 \mathrm{~g}$ of potato per liter $+15 \mathrm{~g}$ of agar) (Heffer Link et al. 2002; Tuite 1969). Isolates were stored at room temperature in the dark in vials containing $5 \mathrm{ml}$ of water, colonized agar plugs, and double-autoclaved corn or oat seed.

Isolates of Pythium and Phytophthora were induced to form reproductive structures by placing agar plugs ( $5 \mathrm{~mm}$ in diameter) in petri plates containing autoclaved pond water diluted 1:1 with sterile distilled water. Sections of bermudagrass (Cynodon spp.) leaf blades measuring $1 \mathrm{~cm}$ in length were boiled for $10 \mathrm{~min}$ in sterile distilled water and added to the pond water. After 24 to $96 \mathrm{~h}$ at room temperature, the cultures were examined, and genus and species were identified based on the procedures and descriptions for Pythium spp. (van der Plaats-Niterink 1981) and Phytophthora spp. (Waterhouse 1963). Zoospore production of Phytophthora spp. was induced by placing agar plugs in petri plates containing dilute CV8 broth and incubating the plates for 48 to $72 \mathrm{~h}$ at room temperature. The plates were then incubated at $4^{\circ} \mathrm{C}$ for $45 \mathrm{~min}$ and returned to room temperature, where the presence of zoospores was determined after 1 to $2 \mathrm{~h}$ (von Broembsen and Deacon 1996).

Sexual reproductive structures were not observed in single cultures of any of the Phytophthora isolates. Phytophthora cryptogea tester strains, mating type A1 and A2, were obtained from S. von Broembsen. Tester strains were grown in paired culture with all of the Phytophthora isolates on CV8 agar for 7 to 10 days (Erwin and Ribeiro 1996). The paired cultures were examined for the presence of oospores and the mating type of each isolate was noted.

Several isolates of Pythium failed to make oospores in culture and were self-sterile. These isolates were paired with each other and with Pythium ultimum var. ultimum isolates to induce gametangia formation (Saunders and Hancock 1994). Isolates and testers were grown on CV8 agar for 3 days and strips of agar $(2 \mathrm{~mm}$ by $5 \mathrm{~cm}$ ) were removed from an actively growing margin of the colony. The strips were paired on CV8 agar and incubated in the dark at room temperature for 21 days prior to examination.

To distinguish between closely related Phytophthora spp., the maximum growth temperature in vitro was determined by growing isolates from 36 to $40^{\circ} \mathrm{C}$ at $1{ }^{\circ} \mathrm{C}$ increments. Due to limited incubator availability, only one temperature was tested at a time. CV8 agar plates (two per isolate) were inoculated with 5 -mm plugs taken from 8- to 12-day-old cultures. Plates were completely randomized within the chamber and sealed in polyethylene bags by replicate. Control plates (two per isolate) were maintained at room temperature in a similar manner to ensure that the transfers were viable. The presence or absence of growth at each respective temperature was determined after 10 days and the assay was repeated.

Molecular identification. The morphological identification of a subset of isolates representing different species and isolates from different fields $(n=43)$ was confirmed with molecular methods. Isolates were grown in liquid culture by inoculating $25-\mathrm{ml}$ aliquots of potato-carrot broth (Tuite 1969) in 50-ml bottles with four agar plugs from actively growing cultures. The bottles were placed in a rotary shaker for 24 to $48 \mathrm{~h}$ at $150 \mathrm{rpm}$ and 22 to $25^{\circ} \mathrm{C}$. The liquid cultures were vacuum filtered through sterile Miracloth (Calbiochem, San Diego, CA) in a Büchner funnel. The mycelium was washed three times with sterile distilled water and dried under vacuum for $2 \mathrm{~min}$. An aliquot of 25 to $75 \mathrm{mg}$ of mycelium was transferred to a 2-ml screwcap tube containing two 5-mm glass beads. Each tube was frozen in liquid nitrogen for $30 \mathrm{~s}$. The frozen tubes were placed in a Mini-BeadBeater-1 (BioSpec Products, Inc., Bartlesville, OK) for $20 \mathrm{~s}$ at 2,500 rpm. This freezing and disruption process was repeated.

DNA was extracted with Qiagen's DNeasy Plant Tissue kit according to the manufacturer's instructions (Qiagen Inc., Valencia, CA) or using a modified quick extraction method. For the modified method, after bead beating, $500 \mu \mathrm{l}$ of buffer $(100 \mathrm{mM}$ Tris-HCl buffer [pH 8.4], $1 \mathrm{M} \mathrm{KCl}$, and $10 \mathrm{mM}$ EDTA) was added to the tubes and samples were incubated at $95^{\circ} \mathrm{C}$ for $5 \mathrm{~min}$ (Thomson and Dietzgen 1995). The samples were vortexed for $15 \mathrm{~s}$ and placed on ice for $5 \mathrm{~min}$. The heating and cooling process was repeated and DNA was stored at $-20^{\circ} \mathrm{C}$.

The extracted DNA was amplified by polymerase chain reaction (PCR) using primers internal transcribed spacer (ITS)-4 and ITS-6 for Pythium and Phytophthora spp. that amplify the ITS region of ribosomal RNA, and primers FM75 and FM80 for Phytophthora spp. that amplify a portion of the mitochondrial DNA cytochrome oxidase II gene (Cooke et al. 2000; Martin and Tooley 2003; Wang et al. 2003; White et al. 1990). DNA extracted with the Qiagen method was diluted 1:100 in PCR-grade pure water prior to amplification while DNA extracted with the quick method was used directly. Each $50-\mu \mathrm{l}$ reaction mixture contained $5.0 \mu \mathrm{l}$ of sample DNA, $0.5 \mu \mathrm{M}$ each primer, $50 \mu \mathrm{M}$ each dNTP, $5.0 \mu \mathrm{l}$ of $10 \times$ PCR buffer, $1.5 \mathrm{mM} \mathrm{MgCl}_{2}$, and $2.5 \mathrm{U}$ of Taq DNA polymerase (Invitrogen Corporation, Carlsbad, CA). The cycling parameters for primers ITS- 4 and ITS- 6 consisted of 1 cycle of $94^{\circ} \mathrm{C}$ for 2 min; 35 cycles of $94^{\circ} \mathrm{C}$ for $30 \mathrm{~s}, 50^{\circ} \mathrm{C}$ for $30 \mathrm{~s}$, and $72^{\circ} \mathrm{C}$ for $1 \mathrm{~min}$; and a final cycle of $72^{\circ} \mathrm{C}$ for $2 \mathrm{~min}$. The cycling parameters for primers FM75 and FM80 consisted of 1 cycle of $94^{\circ} \mathrm{C}$ for $2 \mathrm{~min} ; 35$ cycles of $94^{\circ} \mathrm{C}$ for $1 \mathrm{~min}, 56^{\circ} \mathrm{C}$ for $1 \mathrm{~min}$, and $72^{\circ} \mathrm{C}$ for $1 \mathrm{~min}$; and a final cycle of $72^{\circ} \mathrm{C}$ for $10 \mathrm{~min}$.

After amplification, PCR products were prepared for sequencing with a Quick Clean 5M PCR purification kit (GenScript Corp, Piscataway, NJ) according to the manufacturer's instructions. Each product $(4 \mu \mathrm{l})$ was visualized on a $1.5 \%$ agarose gel in Tris-acetate EDTA buffer and DNA was quantified with a low-mass DNA ladder (Invitrogen Corporation). Samples were submitted to the Biochemistry and Molecular Biology Recombinant DNA and Protein Core Facility at Oklahoma State University for sequencing using the primers ITS-4 and ITS-6 or FM75 and FM80. The resulting sequences were edited and aligned with BioEdit (version 7.0.9.0; IBIS Biosciences, Carlsbad, CA) and consensus sequences were compared with other sequences in GenBank (http://www.ncbi.nlm.nih.gov).

Pathogenicity and virulence to detached pods. Romano type (flat-podded) cultivars of snap bean that expressed differential response to Pythium leak in the field were used (Damicone et al. 2012). 'Roma II' is a processing industry standard that has a prostrate growth habit and is susceptible whereas 'Romano 942' exhibits upright growth habit and is moderately resistant, with about $50 \%$ less diseased pods. Pod disease severity was quantified on the two cultivars to evaluate isolate aggressiveness and to assess the contribution of physiological resistance to the field reaction of Romano 942. 
Pods of marketable maturity and length $(>10 \mathrm{~cm})$ were collected from snap bean plants grown in a greenhouse for 6 to 8 weeks. The pods were stored in polyethylene bags at $4^{\circ} \mathrm{C}$ and inoculated within $48 \mathrm{~h}$ of harvest. The pods were surface disinfested for $3 \mathrm{~min}$ in $70 \%$ ethyl alcohol and $5 \mathrm{~min}$ in $0.6 \%$ sodium hypochlorite and washed under running, deionized water for $2 \mathrm{~min}$. The pods were suspended across two inverted petri dishes (65 $\mathrm{mm}$ in diameter) placed within polyethylene boxes that were lined with moist paper towels.

In a preliminary experiment, wounding pods by making a 2- to 3-mm incision with a sterile scalpel and spraying pods until runoff with sterile distilled water prior to inoculation increased the number of pods exhibiting lesions and lesion length compared with not wounding. Wounds were made 15 to $20 \mathrm{~mm}$ from the tip of the pod between seed, and deep enough to penetrate one side of the carpel. Agar plugs (5 $\mathrm{mm}$ in diameter) were taken from actively growing cultures on CV8 and placed over the pod wounds. Control treatments were inoculated with sterile CV8 plugs. Inoculated pods were maintained at room temperature $\left(22\right.$ to $\left.25^{\circ} \mathrm{C}\right)$ in the laboratory and lesion length was measured after $72 \mathrm{~h}$. Because all of the isolates could not be tested at one time, the experiment consisted of 16 subexperiments that included 11 to 12 isolates along with an untreated check and a reference isolate each of $P$. ultimum var. ultimum (B02) and Phytophthora dreschleri (5B). Reference isolates of each genus were selected arbitrarily among those in the first subexperiment that were virulent on pods. Each subexperiment was arranged in a randomized block design with four replicate pods per isolate and cultivar and was repeated. A preliminary analysis of variance (ANOVA) was run on the reference isolates to insure that there was not a significant $(P=0.05)$ isolate-subexperiment interaction before pooling the data.

The effects of isolate, species, and snap bean cultivar on lesion length were evaluated on the pooled data in an ANOVA using the GLIMMIX procedure of SAS (version 9.2; SAS Institute Inc., Cary, $\mathrm{NC})$. Least-square means were separated where indicated by significant $(P=0.05)$ effects in the ANOVA using the LINES option and the interaction of species or isolates with cultivar was evaluated with the SLICE option of the LSMEANS statement of GLIMMIX.

Pathogenicity and virulence to seedlings. Pathogenicity and virulence to seedlings was determined to assess the ability of isolates to cause damping off. Seed of Roma II snap bean were surface disinfested for $5 \mathrm{~min}$ in $0.6 \%$ sodium hyperchlorite and washed under running, deionized water for $2 \mathrm{~min}$. Seed were soaked for $5 \mathrm{~min}$ in a solution of $0.01 \%$ PCNB (FRAC group 14; Terrachlor $75 \mathrm{WP}$; Uniroyal Chemical Inc., Middlebury, CT) and $0.1 \%$ streptomycin sulfate to control Rhizoctonia damping off and bacterial contaminants. The seed were pregerminated on water agar ( $15 \mathrm{~g} /$ liter of agar) in the dark at room temperature $\left(22\right.$ to $\left.25^{\circ} \mathrm{C}\right)$. Sterile distilled water $(2$ or $3 \mathrm{ml}$ ) was added to the petri dishes once a day to promote germination. After 2 or 3 days, healthy seedlings with radicles $>5 \mathrm{~mm}$ in length were selected for inoculation.

Square, polyethylene pots $(5.7 \mathrm{~cm})$ were filled with $25 \mathrm{~cm}^{3}$ of Metro-Mix 200 soilless growing medium (Sun Gro Horticulture, Bellevue, WA) and watered lightly to pack the medium. Seedlings were inoculated with $1.2-\mathrm{cm}$ plugs taken from actively growing colonies on CV8 agar. Plugs were placed on the potting medium and radicles of the germinating seed were placed in contact with the agar plugs. Sterile agar plugs served as the noninoculated control. An additional $25 \mathrm{~cm}^{3}$ of growing medium was placed over the seed. The pots were watered to run-off once a day. At 10 to 11 days after inoculation, seedlings were evaluated using a disease index from 0 to 5 , where $0=$ healthy seedling with abundant lateral roots and no discoloration; 1 = several lateral roots with slight discoloration; 2 = few or no lateral roots, roots discolored and necrotic; $3=$ seedling died postemergence, little to no root system present, heavy discoloration; $4=$ seedling died preemergence, taproot usually present and discolored; and $5=$ complete death and decay of seed prior to emergence.

The experiment consisted of 19 subexperiments that included 9 to 10 isolates along with an untreated check and the reference isolates described above. Subexperiments were arranged in a randomized block with four replications of one pot per isolate, and the experiment was repeated. Because seedling disease was evaluated on an ordinal scale, data were analyzed using nonparametric techniques (Shah and Madden 2004). Data were ranked from lowest to highest using the Rank procedure of SAS, where the lowest value received a rank of 1 and ties were averaged. Data from the subexperiments were pooled after it was determined that the reference isolate-subexperiment interaction was not significant $(P>0.05)$ in a preliminary ANOVA. The effects of species or isolate were evaluated on the rank transformed data by ANOVA using the ANOVAF option of the MIXED procedure of SAS. The ANOVAF option was invoked using available macros (Shah and Madden 2004). Least-square means of the ranks were compared where indicated by a significant effect in the ANOVA using $t$ tests produced by the PDIFF option of the LSMEANS statement. Letters were assigned to the mean separation grouping using an available macro (Saxton 1998).

Determination of metalaxyl-M sensitivity. The sensitivity of the Pythium and Phytophthora isolates to metalaxyl-M was assessed by measuring mycelial growth on fungicide-amended agar. CV8 agar was prepared and, after autoclaving, amended with increasing concentrations $(0,0.01,0.1,1.0,10.0$, and $100.0 \mu \mathrm{g} / \mathrm{ml})$ of metalaxyl-M as Ridomil Gold 4E (Syngenta Crop Protection, Greensboro, NC). Media (15 ml) was dispensed into 100 -by-15-mm petri plates and allowed to solidify. Isolates were grown on nonamended CV8 agar for 7 to 10 days and 5-mm plugs were cut in the margin of actively growing colonies. The fungicide-amended plates, along with nonamended control plates, were inoculated and incubated at room temperature $\left(22\right.$ to $\left.25^{\circ} \mathrm{C}\right)$ in the dark. For each isolate, three replicate plates of each fungicide concentration were inoculated and the experiment was repeated. The experiment consisted of 14 subexperiments that included 12 to 13 isolates along with the reference isolates described above grown at $10 \mu \mathrm{g} / \mathrm{ml}$. Colony diameter was measured in two directions before the nonamended control reached $100 \mathrm{~mm}$.

Data were pooled over subexperiments after it was determined that the reference isolate-subexperiment interaction was not significant $(P>0.05)$. Relative growth (the percentage of growth compared with the nonamended control) was calculated for each fungicide concentration and replication. The metalaxyl-M concentration that caused a $50 \%$ reduction in mycelial growth $\left(\mathrm{EC}_{50}\right)$ was determined for each isolate and replication by regression analysis of relative growth versus the natural logarithm of fungicide concentration using the REG procedure of SAS. Regression model fit was assessed by examining $P>F, R^{2}$, and selected residual plots. Regression coefficients were output into data files and resulting $\mathrm{EC}_{50}$ values were subjected to ANOVA testing for the effects of isolate or species using the GLIMMIX procedure of SAS. Means were separated as described above. In other studies, isolates were considered resistant if growth was not reduced by $\geq 50 \%$ at $100 \mu \mathrm{g} / \mathrm{ml}$ (Mazzola et al. 2002; Moorman et al. 2002; Taylor et al. 2002). For this study, isolates and species were classified as sensitive $\left(\mathrm{EC}_{50}<1 \mu \mathrm{g} / \mathrm{ml}\right)$, intermediate $\left(\mathrm{EC}_{50}\right.$ from 1 to $\left.<100 \mu \mathrm{g} / \mathrm{ml}\right)$, or resistant $\left(\mathrm{EC}_{50} \geq 100 \mu \mathrm{g} / \mathrm{ml}\right)$ to metalaxyl-M (Taylor et al. 2002).

\section{Results}

Morphological identification of oomycetes. There were 131 Pythium and 46 Phytophthora isolates recovered from snap bean plants with diseased pods (Table 1). In most of the fields sampled, multiple pathogens were recovered and, occasionally, more than one species was recovered from the same pod. In the 10 fields, $P$. ultimum var. ultimum was recovered from all but 1 field and Pythium aphanidermatum was recovered from 6 fields. Phytophthora drechsleri was recovered from two commercial fields which also had the greatest diversity of oomycete species isolated from diseased pods. Several Pythium spp. (five or six) were isolated from pods in addition to $P$. drechsleri. Phytophthora nicotianae was recovered only in 2007 from a research trial at Bixby, OK. Other pod decay pathogens were occasionally recovered from diseased pods, including Rhizoctonia solani, Sclerotinia sclerotiorum, and Sclerotium rolfsii (data not shown). 
Pythium ultimum was the most frequently occurring species, and most isolates of $P$. ultimum fell into the variety ultimum $(n=61)$ because they did not release zoospores upon induction. Only one isolate was classified as $P$. ultimum var. sporangiiferum because it released zoospores upon induction. Many Pythium isolates were identified as $P$. aphanidermatum $(n=50)$ based on morphological characteristics. An isolate of $P$. myriotylum was recovered in 2004 from a commercial production field in Oklahoma.

Several Pythium isolates were identified that failed to make sexual structures, even after pairing. As a result, these isolates were identified solely on the presence of hyphal swellings or the type of sporangium. The isolates that produced only globose swellings $(n=12)$ were classified as Pythium 'group HS'. One isolate produced globose to elongate, nonproliferating sporangia and was classified as Pythium 'group P'.

A few isolates $(n=4)$ produced filamentous, noninflated, or slightly inflated sporangia and did not readily make oospores in self-culture. However, after long-term storage on CV8 agar, microscopic examination revealed the presence of smooth-walled, intercalary or terminal oospores and diclinous antheridia on nonbranched stalks. The four isolates were morphologically identified as $P$. diclinum Tokun.

Most $(n=41)$ of the Phytophthora isolates were identified as Phytophthora drechsleri Tucker. These isolates bore nonpapillate, obpyriform-ovate sporangia. Sporangia were produced by some isolates on solid agar plates if there was free moisture in the plates. However, in liquid cultures, sporangia were abundant and frequently exhibited internal and external proliferation. Irregular to rounded, clustered hyphal swellings were observed in broth cultures. No chlamydospores were observed and no sexual reproductive structures were observed in self-culture. Most (70\%) of the P. drechsleri isolates were mating type A1 and $30 \%$ were mating type A2.

The temperature at which growth of the $P$. drechsleri isolates ceased was determined. All isolates grew well at room temperature ( 22 to $25^{\circ} \mathrm{C}$ ). On average, the $P$. drechsleri isolates had an average maximum temperature for growth of $38^{\circ} \mathrm{C}$. At $39^{\circ} \mathrm{C}$ or above, no growth was observed for most isolates on agar medium. All isolates grew at $36^{\circ} \mathrm{C}$ but growth ceased between 37 and $40^{\circ} \mathrm{C}$.

A few isolates from a research trial at Bixby, OK in 2007 were identified as $P$. nicotianae. No sexual reproductive structures were produced in self-culture. In paired culture, all five of the $P$. nicotianae isolates were determined to be mating type A2.

Molecular identification of oomycetes. In comparing the aligned sequences to those of others in GenBank, sequence homology was greater than $98 \%$ for Pythium ultimum, P. myriotylum, Phytophthora nicotianae, $P$. drechsleri, and Pythium aphanidermatum isolates. All 'group HS' isolates were genetically homologous to P. ultimum (greater than 98\%). P. diclinum isolates were most homologous with $P$. diclinum and $P$. dissotocum Drechsler. The isolates were identified as $P$. diclinum on the basis of morphology. The Pythium 'group P' isolate was most homologous to $P$. vexans de Bary. The sequences of 32 isolates representing the most frequently encountered species were added to the GenBank Database (Table 2).

Pathogenicity and virulence to detached pods. Most oomycete isolates were pathogenic to wounded snap bean pods, causing water-soaked lesions typical of cottony leak from 10 to $50 \mathrm{~mm}$ in length $72 \mathrm{~h}$ after inoculation. There were two isolates of P. ultimum var. ultimum, six isolates of $P$. aphanidermatum (including $24 \mathrm{D}$ and 66C; Table 2), and one isolate of $P$. diclinum that had lesion lengths of less than $5 \mathrm{~mm}$ and were considered nonpathogenic. Typically a dry, red-colored lesion developed directly underneath the agar plug on pods inoculated with nonpathogenic isolates. Lesions did not develop on control pods inoculated with sterile agar plugs.

In the ANOVA for virulence of oomycete species on pods of the two cultivars with differential field reaction, the effects of species $(P<0.01)$ and the species-cultivar interaction $(P=0.02)$ were significant for lesion length. All species were pathogenic to snap bean pods, causing a lesion at least $10 \mathrm{~mm}$ long (Table 1), but species differed in virulence (Table 1 ). Variants of $P$. ultimum ( $P$. ultimum var. ultimum, P. ultimum var. sporangiiferum, and Pythium 'group HS') were the most virulent, usually causing a water-soaked lesion with abundant cottony mycelium. $P$. aphanidermatum isolates were moderately virulent and resulted in water-soaked lesions and abundant aerial mycelium similar to the $P$. ultimum types, although some isolates had a denser and more appressed mycelial growth. Phytophthora drechsleri was also moderately virulent and caused lesions that were water soaked and had aerial mycelium that was more appressed than the Pythium ultimum types. Both $P$. myriotylum and $P$. sylvaticum W. A. Campb. \& F. F. Hendrix were moderately virulent and produced typical cottony leak symptoms. Pythium 'group P', $P$. diclinum, and Phytophthora nicotianae were the least virulent species. The lesions caused by Pythium 'group P' were slightly water soaked and the aerial mycelium was sparse and barely visible. Lesions caused by Pythium diclinum were not typical of cottony leak because they were brown and dry, and aerial mycelium was not visible. Pods inoculated with Phytophthora nicotianae exhibited water soaking and a limited amount of appressed mycelial growth. Virulence of the oomycete species on pods of Roma II and Romano 942 were similar, except for $P$. drechsleri, which was more virulent $(P=0.01)$ on Romano compared with Roma II (Table 1). Averaged over species, lesions lengths did not differ between the cultivars.

Pathogenicity and virulence to seedlings. Species differed in pathogenicity and virulence on seedlings. Both the ANOVA-like test statistic $(P<0.01)$ and the Wald-type statistic $\left(\chi^{2}<0.01\right)$ for the effects of oomycete species on ranks of seedling disease indices were significant. Several species, including $P$. nicotianae, Pythium diclinum, $P$. sylvaticum, and Pythium 'group P' had low disease index ranks that did not differ from the noninoculated control and were considered nonpathogenic to seedlings (Table 3). Phytophthora drechsleri was the most virulent species on seedlings. Most isolates of $P$. drechsleri killed seedlings, resulting in preemergence damping off and some postemergence damping off (Table 2). Sometimes the taproot from the germinating seed was observed but often the seedling was completely rotted. Other oomycete species, including variants of Pythium ultimum ( $P$. ultimum var. ultimum, $P$. ultimum var. sporangiiferum, and Pythium 'group HS') and P. aphanidermatum, were pathogenic to seedlings but less virulent than Phytophthora drechsleri (Table 3). These moderately virulent species had more variable responses on seedlings, ranging from nonpathogenicity to severely reduced and decayed root system to pre- or postemergence damping off (Table 2). Pathogenicity and virulence of individual isolates sometimes differed for pods and seedlings. For example, Pythium aphanidermatum isolate 24D was nonpathogenic on pods but virulent to seedlings (Table 2). Conversely, P. ultimum var. ultimum isolate $34 \mathrm{~A}$ was virulent on pods but nonpathogenic to seedlings.

Sensitivity to metalaxyl-M. Most $(87 \%)$ of the 175 isolates assayed for sensitivity to metalaxyl-M had $\mathrm{EC}_{50}$ values less than $1.0 \mu \mathrm{g} / \mathrm{ml}$ and were classified as sensitive to metalaxyl-M. The

Table 1. Aggressiveness of Pythium and Phytophthora spp. isolated from diseased snap bean pods on detached pods of 'Roma II' and 'Romano 942'

\begin{tabular}{lrrrrr} 
& & \multicolumn{3}{c}{ Lesion length (mm) } \\
\cline { 3 - 6 } Genus and species & $\boldsymbol{n}$ & Roma & Romano & $\boldsymbol{P}>\boldsymbol{F}^{\mathbf{z}}$ \\
\hline Pythium ultimum var. ultimum & 61 & $44.8 \mathrm{a}$ & $45.1 \mathrm{a}$ & 0.89 \\
Pythium aphanidermatum & 50 & $30.0 \mathrm{c}$ & $31.7 \mathrm{bc}$ & 0.28 \\
Phytophthora dreschleri & 41 & $27.3 \mathrm{c}$ & $33.8 \mathrm{bc}$ & $<0.01$ \\
Pythium 'group HS' & 12 & $41.5 \mathrm{ab}$ & $38.5 \mathrm{ab}$ & 0.16 \\
Phytophthora nicotianae & 5 & $12.1 \mathrm{~d}$ & $18.0 \mathrm{ed}$ & 0.15 \\
Pythium diclinum & 4 & $12.6 \mathrm{~d}$ & $13.7 \mathrm{e}$ & 0.86 \\
Pythium myriotylum & 1 & $23.6 \mathrm{~cd}$ & $23.8 \mathrm{de}$ & 0.97 \\
Pythium sylvaticum & 1 & $31.5 \mathrm{bc}$ & $29.1 \mathrm{bcd}$ & 0.73 \\
Pythium 'group P' & 1 & $13.7 \mathrm{~d}$ & $14.3 \mathrm{ed}$ & 0.99 \\
Pythium ultimum var. sporangiiferum & 1 & $37.5 \mathrm{abc}$ & $37.9 \mathrm{abc}$ & 1.00 \\
Mean & $\ldots$ & $27.5 \mathrm{a}$ & $28.1 \mathrm{a}$ & $\ldots$ \\
\hline
\end{tabular}

y Least-square means in a column or averaged over species in a row followed by the same letter are not significantly different at $P=0.05$ according to T grouping from the LINES of option of Proc GLIMMIX.

${ }^{\mathrm{z}}$ Effect of snap bean cultivar on lesion length from the isolate species-cultivar interaction $(P=0.02)$ sliced by species. 
remainder of the isolates (13\%) had $\mathrm{EC}_{50}$ values between 1.0 and $99.9 \mu \mathrm{g} / \mathrm{ml}$ and were considered intermediate in sensitivity. None of the isolates were resistant $\left(\mathrm{EC}_{50} \geq 100 \mu \mathrm{g} / \mathrm{ml}\right)$ to metalaxyl-M.

Sensitivity to metalaxyl-M was compared for each oomycete species. Phytophthora drechsleri, Pythium 'group HS', and Pythium ultimum var. ultimum isolates were the most sensitive species (Table 4). Most isolates of Phytophthora drechsleri (88\%) were highly sensitive $\left(\mathrm{EC}_{50}<0.1 \mu \mathrm{g} / \mathrm{ml}\right)$ compared with Pythium ultimum var. ultimum, which had a broader range of sensitivity and two individuals with intermediate sensitivity (Fig. 1). P. aphanidermatum and $P$. diclinum were the least sensitive species, having intermediate mean sensitivities (Table 4). The sensitivity distribution for isolates of $P$. aphanidermatum was mostly clustered near its intermediate mean sensitivity, and only $14 \%$ of the isolates were highly sensitive (Fig. 1). $P$. ultimum var. ultimum isolate $1 \mathrm{D}$ and $P$. aphanidermatum isolate VxF8 were the least sensitive isolates (Table 2). Averaged over species, Phytophthora spp. (primarily Phytophthora dreschleri) were nearly eightfold more sensitive to metalaxyl-M than Pythium spp. (Table 4).

\section{Discussion}

Pods with symptoms consistent with cottony leak that included a wet rot and abundant white aerial mycelium were sampled over a 6-year period from commercial production fields in Oklahoma and
Missouri and research trials in Oklahoma. A complex of oomycete species that included Pythium and Phytophthora spp. was identified using morphological and molecular methods. The most important Pythium spp., as measured by frequency of occurrence and virulence to both pods and seedlings, were Pythium ultimum var. ultimum and $P$. aphanidermatum. In addition, Pythium 'group HS' isolates were similar in morphology and virulence to $P$. ultimum var. ultimum but failed to produce reproductive structures in culture. Self-sterile isolates of $P$. ultimum var. ultimum from bean have been reported by others (Pfender 1991; Pieczarka and Abawi 1978). P. aphanidermatum and P. ultimum variants were widely distributed among the sampled fields, confirming the previous reports of these Pythium spp. causing cottony leak in snap bean.

Phytophthora spp. were also involved in bean pod decay, although the genus was less widely distributed than the primary Pythium spp. Phytophthora drechsleri caused typical cottony leak symptoms and was the most aggressive pathogen on seedlings. P. drechsleri has not been reported on Phaseolus spp. in the United States (Farr and Rossman 2016) but has been previously reported to cause seedling blight on snap bean in Japan (Erwin and Ribeiro 1996). P. cryptogea Pethybr. \& Laff., a species closely related to $P$. drechsleri, was reported to cause root and basal stem rot of bean in Kentucky (Flowers et al. 1973). P. cryptogea and P. drechsleri are difficult to

Table 2. Pod decay and seedling disease aggressiveness, and fungicide sensitivity of Pythium and Phytophthora spp. isolated from disease snap bean pod pods identified by sequencing ITS-4 and ITS-6 ribosomal RNA (Pythium and Phytophthora spp.) or FM75 and FM80 mitochondrial DNA (Phytophthora spp.)

\begin{tabular}{|c|c|c|c|c|c|c|c|}
\hline \multirow[b]{2}{*}{ Genus and species } & \multirow[b]{2}{*}{ Isolate } & \multirow[b]{2}{*}{ GenBank } & \multicolumn{2}{|c|}{ Pod lesion length (mm) } & \multicolumn{2}{|c|}{ Seedling DI (0-5) ${ }^{w}$} & \multirow{2}{*}{$\frac{\text { Mefenoxam }}{\mathrm{EC}_{50}(\mu \mathrm{g} / \mathrm{ml})^{\mathrm{x}, \mathrm{z}}}$} \\
\hline & & & Roma II ${ }^{\mathbf{x}}$ & Romano 942x & Mean & $\operatorname{Rank}^{\mathbf{y}}$ & \\
\hline Pythium ultimum var. ultimum & $1 \mathrm{D}$ & EU169130 & $37.4 \mathrm{a}-\mathrm{e}$ & $50.0 \mathrm{a}$ & 2.44 & $147 \mathrm{c}-\mathrm{g}$ & $16.071 \mathrm{~b}$ \\
\hline P. ultimum var. ultimum & $11 \mathrm{~A}$ & EU169134 & $49.6 \mathrm{a}$ & $45.1 \mathrm{abc}$ & 1.83 & $118 \mathrm{e}-\mathrm{j}$ & 0.156 def \\
\hline P. ultimum var. ultimum & $25 \mathrm{D}$ & EU245041 & $25.2 \mathrm{~d}-\mathrm{h}$ & $50.0 \mathrm{a}$ & 3.12 & $182 \mathrm{~b}-\mathrm{f}$ & 0.057 ef \\
\hline P. ultimum var. ultimum & $33 \mathrm{~A}$ & EU245037 & $50.0 \mathrm{a}$ & $50.0 \mathrm{a}$ & 1.50 & $101 \mathrm{e}-\mathrm{j}$ & 0.152 def \\
\hline P. ultimum var. ultimum & $34 \mathrm{~A}$ & EU162760 & $50.0 \mathrm{a}$ & $46.6 \mathrm{ab}$ & 0.50 & $57 \mathrm{j}$ & 0.179 def \\
\hline P. ultimum var. ultimum & $62 \mathrm{~A}$ & EU162764 & $50.0 \mathrm{a}$ & $50.0 \mathrm{a}$ & 2.87 & $169 \mathrm{~b}-\mathrm{f}$ & 0.101 ef \\
\hline P. ultimum var. ultimum & B02 & EU162767 & $44.5 \mathrm{abc}$ & $50.0 \mathrm{a}$ & 2.00 & $124 \mathrm{e}-\mathrm{j}$ & $0.121 \mathrm{ef}$ \\
\hline P. ultimum var. ultimum & $\mathrm{B} 03$ & EU253555 & $50.0 \mathrm{a}$ & $50.0 \mathrm{a}$ & 0.87 & 74 hij & $3.844 \mathrm{c}$ \\
\hline P. ultimum var. sporangiiferum & B07 & EU253556 & $37.5 \mathrm{a}-\mathrm{e}$ & $37.5 \mathrm{a}-\mathrm{e}$ & 2.37 & $139 \mathrm{~d}-\mathrm{h}$ & $0.276 \mathrm{def}$ \\
\hline P. ultimum var. ultimum & B14 & EU253557 & $50.0 \mathrm{a}$ & $50.0 \mathrm{a}$ & 1.75 & $115 \mathrm{e}-\mathrm{j}$ & 0.129 ef \\
\hline P. ultimum var. ultimum & VxFWet1 & EU253560 & $50.0 \mathrm{a}$ & $50.0 \mathrm{a}$ & 1.00 & $81 \mathrm{~g}-\mathrm{j}$ & $0.025 \mathrm{ef}$ \\
\hline P. aphanidermatum & $24 \mathrm{D}$ & EU162762 & $1.9 \mathrm{i}$ & $1.3 \mathrm{i}$ & 3.83 & $210 \mathrm{bc}$ & $0.656 \mathrm{def}$ \\
\hline P. aphanidermatum & $35 \mathrm{~A}$ & EU245039 & $44.4 \mathrm{abc}$ & $50.0 \mathrm{a}$ & 3.19 & $184 \mathrm{~b}-\mathrm{e}$ & $1.279 \mathrm{def}$ \\
\hline P. aphanidermatum & $58 \mathrm{~B}$ & EU245040 & $45.0 \mathrm{abc}$ & $50.0 \mathrm{a}$ & 2.00 & $124 \mathrm{e}-\mathrm{j}$ & $1.205 \mathrm{def}$ \\
\hline P. aphanidermatum & $61 \mathrm{~A}$ & EU162761 & $34.1 \mathrm{~b}-\mathrm{g}$ & $50.0 \mathrm{a}$ & 0.87 & 74 hij & $1.484 \mathrm{~d}$ \\
\hline P. aphanidermatum & $61 \mathrm{~B}$ & EU245038 & $19.5 \mathrm{gh}$ & $37.5 \mathrm{a}-\mathrm{e}$ & 3.50 & 198 b-e & 0.649 def \\
\hline P. aphanidermatum & $63 \mathrm{~A}$ & EU162763 & $38.5 \mathrm{a}-\mathrm{d}$ & $45.1 \mathrm{abc}$ & 2.75 & $162 \mathrm{c}-\mathrm{f}$ & $0.815 \mathrm{def}$ \\
\hline P. aphanidermatum & $66 \mathrm{~A}$ & EU169132 & $21.0 \mathrm{fgh}$ & $18.7 \mathrm{~h}$ & 3.62 & $208 \mathrm{bc}$ & 0.051 ef \\
\hline P. aphanidermatum & $66 \mathrm{~B}$ & EU169129 & $18.7 \mathrm{~h}$ & $18.7 \mathrm{~h}$ & 1.25 & $89 \mathrm{f}-\mathrm{j}$ & 0.095 ef \\
\hline P. aphanidermatum & $66 \mathrm{C}$ & EU169131 & $0.7 \mathrm{i}$ & $0.6 \mathrm{i}$ & 5.00 & $277 \mathrm{a}$ & $0.080 \mathrm{ef}$ \\
\hline P. aphanidermatum & $67 \mathrm{~B}$ & EU169128 & $45.2 \mathrm{ab}$ & $43.7 \mathrm{a}-\mathrm{d}$ & 0.87 & 72 hij & $0.056 \mathrm{ef}$ \\
\hline P. aphanidermatum & PA4 & EU162766 & $27.6 \mathrm{~d}-\mathrm{h}$ & $40.4 \mathrm{a}-\mathrm{e}$ & 2.87 & $166 \mathrm{c}-\mathrm{f}$ & $1.222 \mathrm{def}$ \\
\hline P. aphanidermatum & $\mathrm{VxF} 1$ & EU253558 & $43.6 \mathrm{abc}$ & $31.2 \mathrm{~d}-\mathrm{h}$ & 0.75 & 68 hij & $1.349 \mathrm{de}$ \\
\hline P. aphanidermatum & VxF8 & EU253559 & $25.7 \mathrm{~d}-\mathrm{h}$ & $32.6 \mathrm{c}-\mathrm{g}$ & 3.62 & $203 \mathrm{bcd}$ & $31.623 \mathrm{a}$ \\
\hline Phytophthora dreschleri & $4 \mathrm{~A}$ & EU245033 & $26.5 \mathrm{~d}-\mathrm{h}$ & $34.2 \mathrm{~b}-\mathrm{g}$ & 3.25 & $188 \mathrm{~b}-\mathrm{e}$ & 0.022 ef \\
\hline P. dreschleri & $5 \mathrm{~B}$ & EU245034 & $32.4 \mathrm{~b}-\mathrm{h}$ & $38.0 \mathrm{a}-\mathrm{e}$ & 5.00 & $277 \mathrm{a}$ & $0.001 \mathrm{f}$ \\
\hline P. dreschleri & $8 \mathrm{D}$ & EU162765 & $38.2 \mathrm{a}-\mathrm{e}$ & $38.0 \mathrm{a}-\mathrm{e}$ & 3.92 & $218 \mathrm{bc}$ & $0.280 \mathrm{def}$ \\
\hline P. dreschleri & $11 \mathrm{E}$ & EU169135 & $34.9 \mathrm{~b}-\mathrm{f}$ & $35.7 \mathrm{~b}-\mathrm{f}$ & 5.00 & $277 \mathrm{a}$ & $0.004 \mathrm{f}$ \\
\hline P. dreschleri & $17 \mathrm{C}$ & EU169136 & $30.4 \mathrm{c}-\mathrm{h}$ & $30.5 \mathrm{e}-\mathrm{h}$ & 4.62 & $258 \mathrm{ab}$ & 0.027 ef \\
\hline P. dreschleri & $21 \mathrm{D}$ & EU245035 & $23.6 \mathrm{e}-\mathrm{h}$ & $21.7 \mathrm{hg}$ & 5.00 & $277 \mathrm{a}$ & 0.030 ef \\
\hline P. dreschleri & $28 \mathrm{~A}$ & EU245036 & $28.9 \mathrm{~d}-\mathrm{h}$ & $39.1 \mathrm{a}-\mathrm{e}$ & 2.37 & $139 \mathrm{~d}-\mathrm{h}$ & 0.035 ef \\
\hline Pythium myriotylum & $29 \mathrm{~A}$ & EU169137 & $23.6 \mathrm{e}-\mathrm{h}$ & $23.3 \mathrm{fgh}$ & 2.75 & $162 \mathrm{c}-\mathrm{f}$ & $0.559 \mathrm{def}$ \\
\hline
\end{tabular}

${ }^{\mathrm{w}}$ Seedling disease index (DI), where $0=$ abundant lateral roots with no discoloration; $1=$ several lateral roots, slight discoloration; $2=$ few or no lateral roots, roots discolored and necrotic; 3 = seedling died postemergence, little or no root system present, heavy discoloration; $4=$ seedling died preemergence, taproot usually present and discolored; and $5=$ decay and death of seed prior to germination.

${ }^{\mathrm{x}}$ Least-square means in a column by the same letter are not significantly different at $P=0.05$ according to T groupings from the LINES of option of SAS Proc GLIMMIX.

y Ordinal ratings of seedling disease were ranked from lowest to highest using the rank procedure of SAS, where the lowest value received a rank of 1 and ties were averaged. Values in the column followed by the same letter are not significantly different at $P=0.05$ according to $t$ tests obtained from the PDIFF option of SAS Proc MIXED.

${ }^{\mathrm{z}}$ Effective concentration of metalaxyl-M that reduced mycelial growth by $50 \%\left(\mathrm{EC}_{50}\right)$ determined by regression of relative growth (percentage of nonamended control plates) versus the natural logarithm of metalaxyl-M concentrations of $0.01,0.1,1,10$, and $100 \mu \mathrm{g} / \mathrm{ml}$. 
distinguish morphologically (Erwin and Ribeiro 1996). Maximum growth temperature, asexual cultural characteristics, and homology of the ITS region and COX II gene sequences (Erwin and Ribeiro 1996; Olson and Benson 2011) were used to differentiate the two species in this study. $P$. nicotianae was also identified as a cause of downy mildew, although its frequency of isolation and virulence was low. We did not find P. capsici, a widespread pathogen of vegetable crops in the United States that has been periodically observed on cucurbits in Oklahoma.

$P$. drechsleri has a wide host range and causes disease on ornamentals and vegetable crops (Erwin and Ribeiro 1996). The isolates in this study were recovered from fields in the Arkansas River Valley of eastern Oklahoma, where there is a history of irrigated vegetable and ornamental crop production. The fields there are prone to flooding and poorly drained, which favors infection by oomycetes. Wilted plants with basal stem lesions, from which the pathogen was also isolated, were observed along waterways in each of these fields, in addition to the more widely dispersed downy mildew

Table 3. Aggressiveness of Pythium and Phytophthora spp. isolated from diseased snap bean pods to 'Roma II' snap bean seedlings

\begin{tabular}{lccc}
\hline & & \multicolumn{2}{c}{ Seedling DI $(\mathbf{0 - 5})^{\mathbf{z}}$} \\
\cline { 3 - 4 } Genus and species & $\boldsymbol{n}$ & Mean & Rank \\
\hline Pythium ultimum var. ultimum & 61 & 2.55 & $792 \mathrm{c}$ \\
Pythium aphanidermatum & 50 & 2.79 & $854 \mathrm{~b}$ \\
Phytophthora dreschleri & 41 & 4.38 & $1282 \mathrm{a}$ \\
Pythium 'group HS' & 12 & 2.36 & $752 \mathrm{c}$ \\
Phytophthora nicotianae & 5 & 0.87 & $388 \mathrm{~d}$ \\
Pythium diclinum & 4 & 0.97 & $409 \mathrm{~d}$ \\
Pythium myriotylum & 1 & 2.75 & $841 \mathrm{bc}$ \\
Pythium sylvaticum & 1 & 0.50 & $302 \mathrm{~d}$ \\
Pythium 'group P' & 1 & 0.87 & $374 \mathrm{~d}$ \\
Pythium ultimum var. sporangiiferum & 1 & 2.37 & $701 \mathrm{c}$ \\
Control & 1 & 0.69 & $350 \mathrm{~d}$ \\
\hline
\end{tabular}

${ }^{\mathrm{z}}$ Seedling disease index (DI), where $0=$ healthy seedling with abundant lateral roots and no discoloration, 1 = several lateral roots with slight discoloration; 2 = few or no lateral roots, roots discolored and necrotic; $3=$ seedling died postemergence, little to no root system present, heavy discoloration; $4=$ seedling died preemergence, taproot usually present and discolored; and $5=$ complete death and decay of seed prior to emergence. Ordinal ratings of seedling disease were ranked from lowest to highest using the rank procedure of SAS, where the lowest value received a rank of 1 and ties were averaged. Values (least-square means) in a column followed by the same letter are not significantly different at $P=0.05$ according to $t$ tests obtained from the PDIFF option of SAS Proc MIXED.

Table 4. Responses of Pythium and Phytophthora spp. isolated from snap bean pods to metalaxyl-M

\begin{tabular}{|c|c|c|c|c|}
\hline \multirow[b]{2}{*}{ Genus and species } & \multirow[b]{2}{*}{$n$} & \multicolumn{3}{|c|}{$\mathrm{EC}_{50}(\mu \mathrm{g} / \mathrm{ml})^{\mathrm{z}}$} \\
\hline & & Mean & Min & Max \\
\hline Pythium ultimum var. ultimum & 60 & $0.46 \mathrm{~b}$ & 0.02 & 31.6 \\
\hline Pythium aphanidermatum & 50 & $1.35 \mathrm{a}$ & 0.007 & 16.1 \\
\hline Phytophthora dreschleri & 41 & $0.06 \mathrm{~b}$ & 0.001 & 0.42 \\
\hline Pythium 'group HS' & 12 & $0.12 \mathrm{~b}$ & 0.001 & 0.26 \\
\hline Phytophthora nicotianae & 5 & $0.49 \mathrm{ab}$ & 0.22 & 0.77 \\
\hline Pythium diclinum & 4 & $1.39 \mathrm{a}$ & 0.93 & 2.15 \\
\hline Pythium myriotylum & 1 & $0.55 \mathrm{ab}$ & $\ldots$ & $\ldots$ \\
\hline Pythium sylvaticum & 1 & $1.01 \mathrm{ab}$ & $\ldots$ & $\ldots$ \\
\hline Pythium ultimum var. sporangiiferum & 1 & $0.28 \mathrm{ab}$ & $\ldots$ & $\ldots$ \\
\hline Pythium spp. & 129 & $0.80 \mathrm{a}$ & $\cdots$ & $\ldots$ \\
\hline Phytophthora spp. & 46 & $0.11 \mathrm{~b}$ & $\ldots$ & $\ldots$ \\
\hline
\end{tabular}

$\mathrm{z}$ Effective concentration of metalaxyl-M that reduced mycelial growth by $50 \%\left(\mathrm{EC}_{50}\right)$ determined by regression of relative growth (percentage of nonamended control plates) versus the natural logarithm of metalaxyl-M concentrations of $0.01,0.1,1,10$, and $100 \mu \mathrm{g} / \mathrm{ml}$. Min = minimum and Max $=$ maximum. Least-square means by isolate species or isolate genus in a column followed by the same letter are not statistically different according to $\mathrm{T}$ grouping from the lines of option of Proc GLIMMIX. symptoms. It is possible that $P$. drechsleri will be spread to other production fields with movement of soil on equipment, water runoff from infested fields, and irrigation with surface water. Because both mating types of the pathogen were found, it is likely that the pathogen will produce oospores and persist as a problem when susceptible crops are grown. In contrast, we do not anticipate that downy mildew caused by $P$. nicotianae will become an important disease of bean in the region. In virulence assays, isolates recovered were not pathogenic to seedlings and were only weakly virulent to pods. $P$. nicotianae is common on vegetable crops and ornamentals in Oklahoma based on its recovery from samples submitted to the Plant Disease and Insect Diagnostic Laboratory at Oklahoma State University, yet has not been previously reported on bean.

Results of this study have important implications for management of the disease. Application of oomycete-specific fungicides such as metalaxyl-M + copper hydroxide (FRAC group M1) provided good control (80 to $90 \%$ ) of lima bean downy mildew in Delaware (Davey et al. 2004; Dominiak et al. 2002) but was less effective (40\% control) against Pythium leak of snap bean (Damicone et al. 2012). We suspected that metalaxyl insensitivity was involved in the reduced level of disease control on snap bean. However, most of the oomycete isolates in this study were sensitive to metalaxyl-M and only a few exhibited intermediate sensitivity. Metalaxyl-M was not registered for foliar application on bean plants at the time of this study but previous exposure of individuals occurred through seed treatments containing

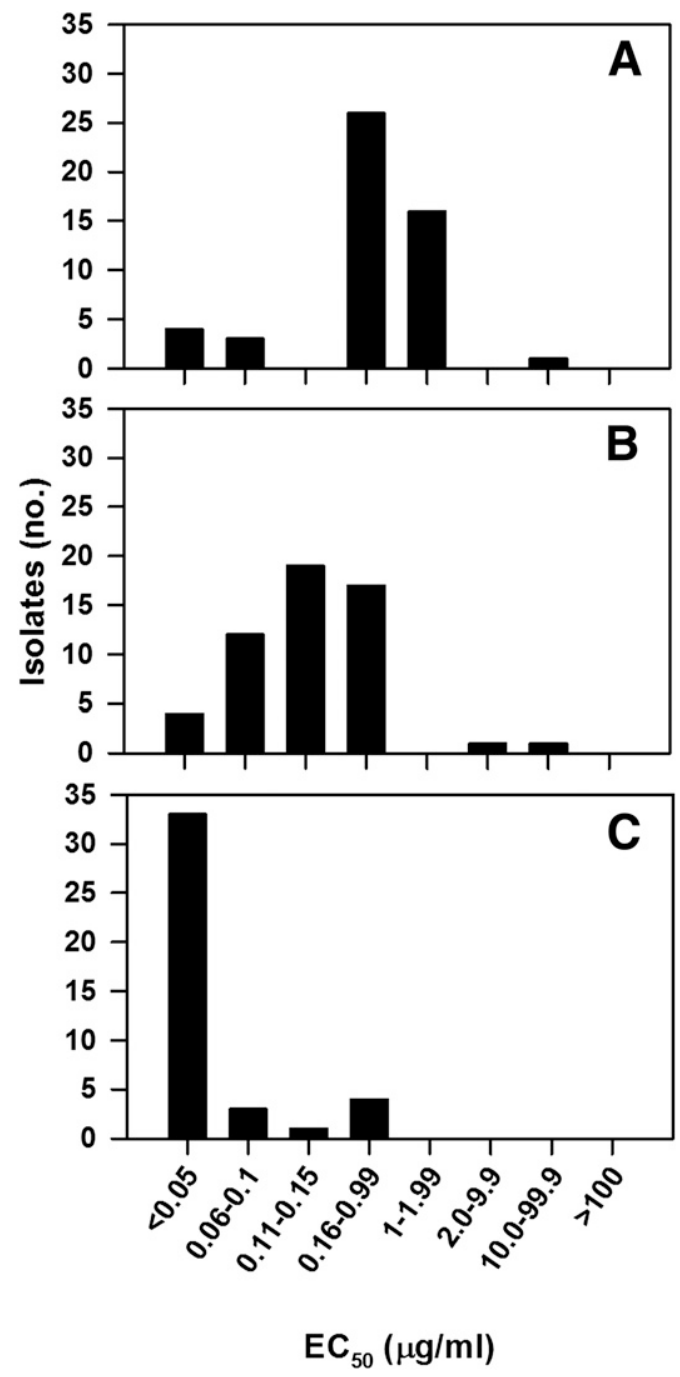

Fig. 1. Sensitivity distributions of A, Pythium aphanidermatum; B, P. ultimum var. ultimum; and C, Phytophthora dreschleri isolates from snap bean pods with cottony leak to metalaxyl-M as measured by the effective concentration that reduced mycelial growth by $50 \%\left(\mathrm{EC}_{50}\right)$. 
metalaxyl or metalaxyl-M; thus, the $\mathrm{EC}_{50}$ values reported here cannot be considered baseline.

Generally, the ranges of metalaxyl-M sensitivity for the oomycete species in this study were similar to those reported for other populations considered sensitive. The sensitivity distribution of Pythium ultimum var. ultimum in this study was similar to that reported for $P$. ultimum that causes leak of potato, except that few of the potato isolates $(<5 \%)$ were resistant $\left(\mathrm{EC}_{50} \geq 100 \mu \mathrm{g} / \mathrm{ml}\right.$ ) (Taylor et al. 2002, 2004). However, Weiland et al. (2014) reported lower mean sensitivities of $P$. ultimum isolates from forest nurseries than those observed in this study. P. aphanidermatum was intermediate in sensitivity as a species in this study, and the range of sensitivity was similar to that reported for the pathogen from greenhouse cucumber (Al-Sadi et al. 2012). Moreover, none of the isolates of P. aphanidermatum from this study were resistant $(<50 \%$ growth inhibition at $100 \mu \mathrm{g} / \mathrm{ml}$ ), as reported for isolates from greenhouse floral crops (Moorman et al. 2002) and turfgrass (Sanders 1984). Phytophthora drechsleri was highly sensitive as a species in this study, in contrast to isolates from pigeon pea (Chauhan and Singh 1987) and from greenhouse floral crops in North Carolina, which were all resistant to $100 \mu \mathrm{g} / \mathrm{ml}$ (Olson and Benson 2011). Results suggest that the moderate level of cottony leak control with metalaxyl-M + copper hydroxide in the field (Damicone et al. 2012) is likely not due to metalaxyl-M resistance alone. Additional factors limiting disease control in this system could be poor canopy penetration and resulting coverage of the lower pods, ineffective application timing, or poor uptake or redistribution of the fungicide into pods.

Cultivars of snap bean such as Romano 942 have been partially resistant to cottony leak compared with Roma II (Damicone et al. 2012). The lower levels of disease could be due to physiological resistance of pods to infection or an upright plant architecture where fewer pods contact the soil compared with Roma II. Overall disease severity on detached pods of the two cultivars was similar, suggesting that physiological resistance does not contribute to differences in levels of cottony leak observed in the field. Within individual oomycete species, differences in lesion length were only significant for $P$. drechsleri, which produced significantly longer lesions on the partially resistant Romano 942.

The diverse oomycetes that cause cottony leak in our region complicate disease management. Pythium ultimum var. ultimum is considered a low-temperature pathogen, most active below $25^{\circ} \mathrm{C}$, whereas $P$. aphanidermatum, Phytophthora drechsleri, and $P$. nicotianae are high-temperature pathogens, most active above $25^{\circ} \mathrm{C}$ (Erwin and Ribeiro 1996; Lumsden et al. 1976; Pieczarka and Abawi 1978). Snap bean crops in Oklahoma and nearby states are either planted in the spring for harvest in early summer, when temperatures are increasing, or planted in late summer for harvest in October, when temperatures are cooling. Therefore, the use of planting date to escape favorable conditions for disease development is not likely to be effective. Deep plowing has been shown to reduce soil populations of Pythium spp. and damping off in bean compared with disking (Lewis et al. 1983). However, plowing is discouraged by agencies that promote soil conservation and is generally no longer practiced in the region. Planting of bean cultivars with architectural resistance is promising for control of Pythium leak (Damicone et al. 2012) but cultivar screening against $P$. drechsleri is needed. Application of metalaxyl + copper hydroxide, now registered for control of cottony leak and downy mildew on legume vegetable crops, has not been widely used in the region because of low, narrow profit margins in processing snap bean and difficulty in anticipating disease outbreaks. Development of cultural practices that minimize pod contact with soil, pod wounding, and soil splashing onto pods may be beneficial.

\section{Acknowledgments}

Approved for publication by the Director of the Oklahoma Agricultural Experiment Station. This research was funded, in part, by the Oklahoma Agricultural Experiment Station and United States Department of Agriculture Cooperative State Research, Education, and Extension Service Southern region IPM agreement number 2004-04618.

\section{Literature Cited}

Adegbola, M. O. K., and Hagedorn, D. J. 1969. Symptomology and epidemiology of Pythium bean blight. Phytopathology 59:1113-1118.

Adegbola, M. O. K., and Hagedorn, D. J. 1970. Host resistance and pathogen virulence in Pythium blight of bean. Phytopathology 60:1477-1479.

Al-Sadi, A. M., Al-Ghaithi, A. G., Al-Balushi, Z. M., and Al-Jabri, A. H. 2012 Analysis of diversity in $P$. aphanidermatum populations from a single greenhouse reveals phenotypic and genotypic changes over 2006-2011. Plant Dis. 96: 852-858.

Chauhan, V. B., and Singh, U. P. 1987. A naturally occurring resistant forma specialis of Phytophthora drechsleri to metalaxyl. J. Phytopathol. 120:93-96.

Cooke, D. E. L., Drenth, A., Duncan, J. M., Wagels, G., and Brasier, C. M. 2000. A molecular phylogeny of Phytophthora and related Oomycetes. Fungal Genet. Biol. 30:17-32.

Damicone, J. P., Olson, J. D., and Kahn, B. A. 2012. Cultivar and fungicide effects on Pythium leak of snap bean. Online publication. Plant Health Prog. doi: 10.1094/PHP-2012-0418-01-RS

Davey, J. F., Mulrooney, R. P., Evans, T. A., and Carroll, R. B. 2004. Fungicide efficacy and timing trials for the control of downy mildew of baby lima bean. (Abstr.) Phytopathology 94:S34.

Dominiak, J. D., Mulrooney, R. P., and Evans, T. A. 2002. Fungicide evaluation for the control of downy mildew of baby lima beans, 2001. Online publication. Fungic. Nematicide Tests 57:V003. doi:10.1094/FN57

Drechsler, C. 1952. Bean stem rot in Maryland and Delaware caused by several Pythium species. Plant Dis Rep. 36:13.

Erwin, D. C., and Ribeiro, O. K. 1996. Phytophthora Diseases Worldwide. American Phytopathological Society, St. Paul, MN.

Evans, T. A., Mulrooney, R. P., Gregory, N. F., and Kee, E. 2007. Lima bean downy mildew: Impact, etiology, and management strategies for Delaware and the Mid-Atlantic region, U.S. Plant Dis. 91:128-135.

Farr, D. F., and Rossman, A. Y. 2016. Fungal Databases. Online publication. Systematic Mycology and Microbiology Laboratory, United States Department of Agriculture-Agricultural Research Service. http://nt.ars-grin.gov/fungaldatabases/

Flowers, R. A., Erwin, D. C., and Hendrix, J. W. 1973. Isolation of Phytophthora cryptogea from bean in Kentucky. Plant Dis. Rep. 57:190-191.

Gevens, A. J., Donahoo, R. S., Lamour, K. H., and Hausbeck, M. K. 2008 Characterization of Phytophthora capsii causing foliar and pod blight of snap bean in Michigan. Plant Dis. 92:201-209.

Hagedorn, D. J. 1991. Pythium blight. Pages 23-24 in: Compendium of Bean Diseases. R. Hall, ed. American Phytopathological Society, St. Paul, MN.

Harter, L. L., and Whitney, W. A. 1927. A transit disease of snap beans caused by Pythium aphanidermatum. J. Agric. Res. 34:443-447.

Heffer Link, V., Powelson, M. L., and Johnson, K. B. 2002. Oomycetes. Online publication. Plant Health Instruct, doi:10.1094/PHI-I-2002-0225-01

Hunger, R. M., Hamm, P. B., Horner, C. E., and Hansen, E. M. 1982. Tolerance of Phytophthora megasperma isolates to metalaxyl. Plant Dis. 66: 645-649.

Jeffers, S., and Martin, S. B. 1986. Comparison of two selective media for Phytophthora and Pythium species. Plant Dis. 70:1038-1043.

Lewis, J. A., Lumsden, R. D., Papavisas, G. C., and Kantzes, J. G. 1983. Integrated control of snap bean diseases caused by Pythium spp. and Rhizoctonia solani. Plant Dis. 67:1241-1244.

Lucas, B., and Griffiths, P. D. 2004. Evaluation of common bean accessions for resistance to Pythium ultimum. HortScience 39:1193-1195.

Lumsden, R. D., Ayers, W. A., Adams, P. B., Dow, R. L., Lewis, J. A., Papavizas, G. C., and Kantzes, J. G. 1976. Ecology and epidemiology of Pythium species in field soil. Phytopathology 66:1203-1209.

Martin, F. N., and Tooley, P. W. 2003. Phylogenetic relationships among Phytophthora species inferred from sequence analysis of mitochondrially encoded cytochrome oxidase I and II genes. Mycologia 95:269-284.

Matheron, M. E., and Porchas, M. 2000. Comparison of five fungicides on development of root, crown, and fruit rot of chili pepper and recovery of Phytophthora capsici from soil. Plant Dis. 84:1038-1043.

Mazzola, M., Andrews, P. K., Reganold, J. P., and Lévesque, C. A. 2002. Frequency, virulence, and metalaxyl sensitivity of Pythium spp. isolated from apple roots under conventional and organic production systems. Plant Dis. 86: 669-675.

Moorman, G. W., Kang, S., Geiser, D. M., and Kim, S. H. 2002. Identification and characterization of Pythium species associated with greenhouse floral crops in Pennsylvania. Plant Dis. 86:1227-1231.

Olson, H. A., and Benson, D. M. 2011. Characterization of Phytophthora spp. on floriculture crops in North Carolina. Plant Dis. 95:1013-1020.

Parra, G., and Ristaino, J. B. 2001. Resistance to mefanoxam and metalaxyl among field isolates of Phytophthora capsici causing Phytophthora blight of bell pepper. Plant Dis. 85:1069-1075.

Pfender, W. F. 1991. Pythium diseases. Pages 11-13 in: Compendium of Bean Diseases. R. Hall, ed. American Phytopathological Society, St. Paul, MN

Pieczarka, D. J., and Abawi, G. S. 1978. Populations and biology of Pythium species associated with snap bean roots and soils in New York. Phytopathology 68: 409-416.

Preston, D. A. 1945. Host index of Oklahoma plant diseases. Okla. Agric. Mech. College Agric. Exp. Stn. Tech. Bull. No. T-21. 
Sanders, P. L. 1984. Failure of metalaxyl to control Pythium blight on turfgrass in Pennsylvania. Plant Dis. 68:776-777.

Saunders, G. A., and Hancock, J. G. 1994. Self-sterile isolates of Pythium mate with self-fertile isolates of Pythium ultimum. Mycologia 86:660-666.

Saxton, A. M. 1998. A macro for converting mean separation output to letter groupings in Proc Mixed. Pages 1243-1246 in: Proc. 23rd SAS Users Group Int. Nashville, TN. SAS Institute, Cary, NC.

Schwartz, H. F. 1991. Downy mildew. Page 19 in: Compendium of Bean Diseases. R. Hall, ed. American Phytopathological Society, St. Paul, MN.

Shah, D. A., and Madden, L. V. 2004. Nonparametric analysis of ordinal data in designed factorial experiments. Phytopathology 94:33-43.

Taylor, J. H., and Rothrock, C. S. 2006. Influence of cultural practices and the environment on pod rot incidence in green beans in the mid-south. (Abstr.) Phytopathology 96:S113.

Taylor, R. J., Salas, B., and Gudmestad, N. C. 2004. Differences in etiology affect mefenoxam efficacy and the control of pink rot and leak tuber diseases of potato. Plant Dis. 88:301-307.

Taylor, R. J., Salas, B., Secor, G. A., Rivera, V., and Gudmestad, N. C. 2002. Sensitivity of North American isolates of Phytophthora erythroseptica and Pythium ultimum to mefenoxam (metalaxyl). Plant Dis. 86:797-802.

Thomson, D., and Dietzgen, R. G. 1995. Detection of DNA and RNA plant viruses by PCR and RT-PCR using a rapid virus release protocol without tissue homogenization. J. Virol. Methods 54:85-95.
Tuite, J. 1969. Plant Pathological Methods, Fungi and Bacteria. Burgess Publishing Company, Minneapolis, MN.

van der Plaats-Niterink, A. J. 1981. Monograph of the Genus Pythium. Studies in Mycology, Vol. 21. Centraalbureau voor Schimmelcultures, Baarn, The Netherlands.

van Jaarsveld, E., Wingfield, M. J., and Drenth, A. 2002. Effect of metalaxyl resistance and cultivar resistance on control of Phytophthora nicotianae in tobacco. Plant Dis. 86:362-366.

von Broembsen, S. L., and Deacon, J. W. 1996. Effects of calcium on germination and further zoospore release from zoospore cysts of Phytophthora parasitica. Mycol. Res. 100:1498-1504.

Wang, P. H., Wang, Y. T., and White, J. G. 2003. Species-specific PCR primers for Pythium developed from ribosomal ITS1 region. Lett. Appl. Microbiol. 37: 127-132.

Waterhouse, G. M. 1963. Key to the Species of Phytophthora de Bary. Commonwealth Mycological Institute, Kew, England.

Weiland, J. E., Santamaria, L., and Grünwald, N. 2014. Sensitivity of Pythium irregulare, $P$. sylvaticum, and $P$. ultimum from forest nurseries to mefenoxam and fosetyl-Al, and control of Pythium damping off. Plant Dis. 98:937-942.

White, T. J., Bruns, T. D., Lee, S., and Taylor, J. 1990. Amplification and direct sequencing of fungal ribosomal RNA genes for phylogenetics. Pages 315-322 in: PCR Protocols: A Guide to Methods and Applications. M. A. Innis, D. H Gelfand, J. J. Sninsky, and T. J. White, eds. Academic Press, San Diego, CA. 